\title{
Mellem ontologi og politik
}

Slavoj Žižek:

Less than Nothing - Hegel and the Shadow of Dialectical

Materialism

Verso, 2012

1056 sider, 49,95 USD

Less Than Nothing - Hegel and the Shadow of Dialectical Materialism er Slavoj Žižeks filosofiske magnum opus. Værket ligger i forlængelse af det filosofiske projekt, Žižek forsøger at udvikle; et projekt, der tager sit udgangspunkt $i$ en kritik af tidens postmoderne idealistiske strømning. I modsætning til denne strømning vil Žižek udvikle en ny materialisme: "Lenin's Materialism and Empirio-Criticism has to be thoroughly rewritten" (s. 912). Dette projekt er den røde tråd i en række af Žižeks værker, bl.a. Tarrying with the Negative (1993), The Ticklish Subject (1999) og The Parallax View (2006).

Måske overraskende for nogen, må sådan et projekt tage udgangspunkt i Hegel. Hegel og den tyske idealisme er det filosofihistoriske udgangspunktet for Žižeks projekt. Denne "mother of all Gangs of Four" (Kant, Fichte, Schelling og Hegel) leverer udgangspunktet for filosofiens "mulighedsbetingelser", som udarbejdet af Alain Baidou (s. 9). Pointen er her at gentage Hegel, fordi kun gennem gentagelse er det muligt at overskride. Denne gentagelse må desuden foregå gennem Jaques Lacan. Hegel og den tyske idealisme var det filosofiske projekt, der opstod ved modernitetens begyndelse. På kanten af moderniteten må filosofien derfor gå gennem en gentagelse af Hegel.

Der er tre ting, der skal understreges i forhold til Žižeks filosofiske projekt. Det første er det Lacanianske subjekt. Genstand for utallige fortolkninger er det centrale ved det Lacanianske subjekt, dets splittethed. Til forskel for al ego-psykologi opererer Lacan med et splittet subjekt, dvs. et subjekt, som er ikke-identisk med sig selv, splittet af dets introduktion i sproget og relationen til den Andens begær. For Žižek har dette splittede subjekt afgørende be- 
tydning, idet subjektet kun er for så vidt det fejler i at aktualisere sig selv - subjektet er så at sige dette mislykkede forsøg. Denne ikke-identitet betyder, at subjektet for Žižek repræsenterer en inkonsistens i den symbolske orden - det sted, hvor det reelle trænger sig på. På den måde tilhører subjektet også det reelles register. Den symbolske-imaginære orden er repræsentationen af eller forklaring på verden for os; dvs. vores transcendentale horisont. Noget forstyrrer dog denne orden, hvilket betyder, at repræsentationen af verden ikke kan blive total. Forklaringen eller repræsentationen er ikke-hel, idet den altid bryder sammen et sted, der ikke kan forklares inden for den symbolske-imaginære orden. Dette sted er subjektet. Den anden side af subjektet er objekt $a$. Hvis subjektet er selve inkonsistensen i den symbolske orden; det, der gør, at den symbolske orden altid vil cirkulere om noget, den ikke kan forklare, da er objekt $a$ årsagen til dette subjekt. Her kommer den strukturalistiske pointe ind i billedet, nemlig den, at en mangel ligeså vel kan have en positiv effekt. Objekt $a$ er det, der mangler; men det er ingenting, der mangler. Vi kan ikke determinere en bestemt entitet som værende manglende (f.eks. Gud, Materien, etc.). Objekt $a$ er således mindreend ingenting, det er selve manglen. Žižzek formulerer det også således: "[T] he subject is correlated with the very impossible/Real object that has to be excluded from the field of reality so that the subject can relate to this field" (s. 665). Disse første to ting, som Žižek tager med fra Lacan, nemlig subjekt og objekt som to sider af samme sag (sagen værende det reelle), fører nu over til det tredje punkt: karakteristikken af det reelle. Det reelle er denne subjekt/ objekt tvist i det symbolske. Det, som forhindrer det symbolske i at blive helt. Dette er på en måde traditionel ideologikritik, idet vores symbolske orden eller den herskende ideologi bestemmes som værende ikke-naturlig. Afsløringen af ideologien som ideologi. Men Žižek går også ud over denne traditionelle ideologikritik, idet han henviser til det reelle som betingelsen for at kunne tale om sandhed. Hos Žižek eksisterer der således ikke kun diskurser. Men negationen af postulatet om at alt er diskurs: nemlig at der er noget, som ikke er diskurs (f.eks. det materielle, begæret el.lign.), er ikke radikal nok. Negationens negation - at der ikke er noget, som ikke er diskurs - er det, Žižek gerne vil frem til. Dette betyder dog ikke, at vi blot kommer tilbage til 'alt er diskurs', men 
tværtimod at ikke-alt er diskurs.

Det er Lacan, der udvikler denne pas-tout logik i forbindelse med den feminine seksualitet. Logikken indebærer, at maskulinitet er en universel funktion baseret på den falliske undtagelse. Alle mænd er fuldt ud determineret af den falliske funktion, undtagen urfaderen, som står uden for denne funktion, og dermed overhovedet muliggør den (reglen er baseret på undtagelsen). Heroverfor står den feminine seksualitet, for hvilken negationens negation gælder, nemlig at der ikke findes én kvinde, for hvem den falliske funktion ikke gælder. Her kan undtagelsen altså ikke konstituere reglen, hvorfor reglen aldrig kan gives den helhed, som undtagelsen giver den maskuline seksualitet (s. 756). Den feminine seksualitet er således ikkehel, pas-tout, dvs. ikke-totalisérbar. Žižek placerer nu denne logik på det seksuelle forhold som helhed, dvs. at det seksuelle forhold er et ikke-forhold, det er ikke-totalisérbart. Det seksuelle forhold er den umulighed, som går forud for enhver symbolisering af dette forhold. Det er selve det forhold, at symboliseringen aldrig kan afsluttes og realiseres som en helhed (s. 612-13, 746 \& 796). Žižek tager skridet videre og ontologiserer denne ikke-helhed: "'[S]exuality' is the way the ontological deadlock, the incompleteness of reality in itself, is inscribed into subjectivity. It is not a subjective distortion of objective reality, but a subjective distortion which is directly identical with the non-All, the inconcistency/out-of-jointness, or reality itself" (s. 745).

Žižeks brug af Lacan bliver nu udgangspunktet for hans Hegellæsning. Bevægelsen fra Kant til Hegel er ifølge Žižek en bevægelse fra det transcendentale subjekt adskilt fra den noumenale 'virkelighed' til inkluderingen af dette transcendentale subjekt i virkeligheden selv (s. 389-90 \& 643-45). Den kantianske adskillelse af de transcendentale mulighedsbetingelser for enhver erkendelse af fænomenerne og den transcendente noumenale virkelighed bliver hos Hegel indskrevet i selve denne noumenale virkelighed (som derfor ophører med at være noumenal på transcendent vis). For at forklare dette behøves en teori om det reelle i subjektet: "The problem is not to think the Real outside of transcendental correlation, independently of the subject; the problem is to think the Real inside the subject, the hard core of the Real in the very heart of the subject." (s. 644). Sagt på en anden måde: Den subjektive transcendentale 
horisont, der adskiller vores erkendelse fra 'virkeligheden', bliver indskrevet i denne virkelighed selv. Det er en egenskab ved virkeligheden, at den er ikke-hel, derved at subjektiviteten er en konstitutiv del af den. Virkeligheden er "non-All", som Žižek siger, hvilket betyder, at der er ingenting, som ligger bag fænomenerne, og som ville kunne sikre deres totalisérbarhed. Ingenting skal her forstås som en ontologisk kategori, som en inkonsistens i virkeligheden. Subjektiviteten er derfor (også hos Hegel) splittet. Der er ikke noget metapunkt, hvorfra subjektet kan beskrive sig selv. Objektet er selve denne umulighed for subjektet at tage sig selv som objekt (s. 645). En umulighed, som allerede Kant erkendte, men som Hegel ontologiserer. Hegels absolutte viden er netop den endelige erkendelse af denne begrænsning (s. 388). En begrænsning, som netop er absolut, og derfor kan siges at tilhøre (eller være) det reelle selv, og ikke bare en egenskab ved et transcendental subjekt (s. 388-89). Projektet er, hvad Adrian Johnston har kaldt "transcendental materialisme", nemlig "to inscribe this transcendental correlation into the Thing itself' (s. 906). Žižek beskriver opgaven for projektet således: "[T] he true problem is not to think pre-subjective reality, but to think how something like a subject could have emerged within it" (s. 642).

Værket formår at formulere skitsen af en ny filosofi, som står på skuldrene af en gennemkritiseret filosof, nemlig Hegel. Žižek filosofi er ikke en 'tilbagevenden til Hegel' eller noget i den retning, men derimod en 'gåen igennem' Hegel, for på den anden side at kunne stå med muligheden for at formulere en filosofi, der er i stand til at tage modernitetens udvikling siden Hegel i betragtning. Der melder sig dog et problem. Žižek egen citation af Alenka Zupančič kan meget vel bruges i denne sammenhæng: "If the symbolic is productive of being, and not only of the ways (and norms) of being, it is because of what prevents being to be qua being, because of its inherent contradiction, which is precisely not symbolic, but real" (s. 960). Problemet er forholdet mellem det reelle og det symbolske. Hvis det reelle er ontologisk inkonsistens, og det symbolske ligeledes er inkonsistent, opstår spørgsmålet om forholdet mellem disse to. Problemet går videre end det, fordi, som Žižek selv påpeger: "not every epistemological limitation is an indication of ontological incompleteness" (s. 907). Det rejser i sig selv spørgs- 
målet: hvilke epistemologiske begrænsninger er faktiske indikationer på ontologisk inkonsistens, og hvilke er ikke? Žižek leverer selv et meget kort svar: "But does this mean that we end up in a kind of idealism of the symbolic - what we experience as 'reality' is symbolically constructed, and even the Real which eludes the grasp of the symbolic is a result of the immanent failure of the symbolic? No, because it is through this very failure to be itself that the symbolic touches the Real' (s. 959). Spørgsmålet om forholdet mellem det symbolske og reelle besvares ikke i tilstrækkelig grad. Det synes dog klart, at Žižek altså ikke mener, at det symbolske producerer det reelle, fordi vi i så fald ville ende op i en idealisme; den idealistiske fælde, han netop beskylder den nutidige postmoderne filosofi for at falde i. For at løse problemet behøves der altså en teori om, hvorledes subjektivitet overhovedet er ontologisk mulig, en teori Žižek leverer skitsen til i Less Than Nothing.

Žižeks værk er skelsættende inden for den nyere Hegel-tolkning. Værket brydes dog også med nogle af de mest fremtrædende Hegel-forskere i verden i dag, heriblandt Robert Pippin. Værket intenderer dog at gå videre end dette. På kanten af moderniteten eller i The End Times, som er titlen på et andet af Žižeks nyere værker, åbnes der en mulighed for en ny filosofi. Žižeks værk er et bidrag til åbningen af denne nye filosofi, snarere end det er et forsøg på at fuldføre projektet. Dette projekt vedrører ikke bare den mere teoretiske del af filosofien, men ligeså meget (eller måske specielt) alle andre sider af livet. Derfor er det også meget sigende, at konklusionen på værket har titlen "The Political Suspension of the Ethical". Projektet har nogle helt klare politiske konsekvenser; det åbner op for en tænkning af, hvordan ægte politisk intervention i dag er mulig (og hvor den bestemt ikke er mulig). Det politiske og det ontologiske er to sider af samme sag.

Esben Bogh Sorensen 